\title{
RHYMES AS MNEMONIC IN MEMORIZING QUR'AN
}

\author{
Nadya Utari Boru Sitanggang \\ Dayah Jeumala Amal, Pidie Jaya Aceh \\ nadia00772@gmail.com
}

\begin{abstract}
Mnemonic is a method to memorize or recall a memory easily. People with deep oral tradition use it to recall their memories, while people with literacy tradition use formulaic to recall their memories. In Islamic tradition, both mnemonic and formulaic are used in memorizing Qur'an. This research based on an experiment in case of difficulty in memorizing Qur'an. R\&D (research and development) method is employed here to examine the hypothesis in the experiment. The hypothesis is that people can memorize Qur'an easily if they recognize the rhymes of Qur'an. The notion is examined by relearning Iqra' (a module contained six chapters to learn basic Arabic recitation which used in Indonesia) and underlining method. The examination showed that students who were guided by those modules were helped in memorizing Qur'an easily.
\end{abstract}

Keywords: mnemonic, formulaic, memorizing Qur'an, rhyme.

\section{Introduction}

On June 2017, few months ago, the boarding school that I teach in held its annually program called "Gema Ramadhan". It is the activity that is only obliged to grade 3 either in junior high school or senior one. The students are asked to memorize some parts of Qur'an; the juniors must memorize juz 30 while seniors must memorize juz 1 and 30 in 20 days of Ramadan and they must stay in the dormitory. For who can exceed the targets, which is at least more than two juz(s) than they have to memorize, will get the prices and scholarships from the school. While, they who can not reach the target in 20 days, during the program, will get punishment from the school. They must finish the target even the program has already ended and they got two extended days to stay in the dormitory when other students are permitted to go home. Moreover, they also had to continue the obligation to finish the target after Ied (Idul Fitri). I have been asked by the chief of committee of this program to handle the students who got punishment. Then I get very surprised by how difficult for them to memorize the Qur'an, even it is juz 'Amma (30) which has been familiar for them since they are a kid.

I and the students who got the punishments have passed a month after holiday, from July 6, 2017 until August 5, 2017. I did not make any certain schedule for the students to deliver their recitation or memorization, so they can come if they were ready to deliver their memorization or to learn Iqra`. Before delivering their memorization I asked them to recite the chapter or verse that they wanted to deliver. While listening to their recitation I corrected the errors of tajwid and makharijul huruf in it. I frequently asked them what ordinance (hukm tajwid) is prevailed to the parts that they read wrongly. Most of them did not know the answer. In other times, I corrected the way they pronounced the verses, especially in certain words, most of them were troubled in pronouncing 'ain, tha, dhad, $d z a$, and mostly mispronouncing $k a f$ and $q a f$. After listening to the recitation and correcting it, they delivered the memorization. Unfortunately, even I have corrected the recitation properly; they kept reading it as if I have not corrected yet. Simply, I assumed that the main problem of their difficulty in memorizing Qur'an is because they can not read Qur'an well. I identified that the problem arises from the errors of pronouncing the letter of Arabic (Huruf al-Hija iyyah) and ignoring tajwid or even 
misapplication of it. Besides, they also did not recognize the rhymes that spread in verses they were memorizing. Especially, the rhymes in juz 30. Most of the chapters (surah) have many kinds of rhymes in its verses. I assumed that elements must have helped them in memorizing Qur'an while they do not. As their supervisor, I tried hard to help them in memorizing Qur'an easily and coincidentally remembered Walter Ong's book "Orality and Literacy", a book that I knew from my lecturer.

There is a part of the book told about people with orality tradition also have a way to recall the memories that they have ever had in mind. They are not same as people with literacy traditions who can go back to the sources that they gained the memories, it is the books or pamphlets or traffic signs or any written materials. There is no text for them to look back and even to make sure whether they have saved the things rightly or wrongly in their memories. Nonetheless, they have it. The only way to recall them is to shape a memorable thought, which are in mnemonic shapes (Ong: 2005).

Mnemonic is a method to memorize something easily by transforming, usually by encoding, the new, unfamiliar information into something that has already shaped in memory before, or has already been in the memorizer's long-term memory (Bakken: 2011). I remember when I was the first grade in senior high school, my Chemistry teacher taught us how to memorize chemical elements periodic-table easily. It is by encoding each element as a word or a name, then relating it to the element in the next row of the table and establishing unique sentences of the codes. We were asked to look for a word that representing each element by looking for another similar-but-familiar name or word. For example, on the first row of the table, there are $\mathrm{H}$ (Hydrogen), Li (Lithium), $\mathrm{Na}$ (Natrium/), K (Kalium), Rb (Rubidium), Cs (Cesium), Fr (Francium). The representation that could be made, such as:

Hai Li Na, Kenapa Rubi Cs Frustasi? (Hi Li Na, why does Rubi get frustrated?)

It is a unique shape of the transforming code that represents the first row of the table. The sentence is quite familiar or at least used in the daily and word "Frustasi" is a catchy enough word to remember and it makes the sentence unique. Lately, I know that this method is one of mnemonics tools called acrostics. There are other tools of mnemonics that we can apply to memorize or remember and recall the memory easily, they are (Student Academic Resource Center:-) :

a. Music, inserting information into a set of tones as many children do to memorize alphabet by singing $\mathrm{A}$ to $\mathrm{Z}$ in $\mathrm{ABC}$ song. In Islamic schools, Arabic and Arabic grammar (nahw-sarf) are sometimes taught by singing a song. I even have ever listened a class of civics education singing a song about signs of Pancasila and students are helped to memorize them faster.

b. Name, the first letters of the list of the information are taken and all of them united to be arranged like a person's name. One of the most popular example of this tool using is: ROY G BIV for Red, Orange, Yellow, Green, Blue, Indigo, and Violet, the colors of the spectrum.

c. Name of expression, this tool works by making a unique and familiar expression which taken from the first letter of the information. Then, the first letters are initialized by something catchy and familiar. It is the tool I use to memorize periodic-table using acrostics method.

d. Model mnemonics, as far as I know, can be concluded as shape. The shape of a thing can be used as a tool to memorize information. The closest example comes from our body. The little kids are usually taught by their parents how to know the numbers of dates in a month, whether it is $28,29,30$, or 31 . They are taught that dent and kern shaped on their hand when they fold the fingers inside can determine the numbers of date. 
e. Ode and rhyme are tools that applicated by making information into something easy to listen as in poems or song lyrics.

Mnemonic is one of the characteristics of orality tradition, while people in literacy tradition used formulaic(Ong: 2005). The easiest way to differ both is that in mnemonic people remember the code or indication or the shape or sound, while in formulaic people remember the structure or order. In memorizing Qur'an, these methods may be employed in the process.

There are many books or literature about the tips and tricks to memorize Qur'an, but, only less of those are academic work. In Sunan Kalijaga State Islamic University, many students researched about this discourse, such as; institution of memorizing Qur'an, the difficulty in memorizing Qur'an, the motivations, etc. Nevertheless, I have never found the research about examining a hypothesis regarding memorizing Qur'an. This research will attempt to examine a hypothesis that people will memorize Qur'an easily if they recognize the rhymes of Qur'an, while rhyme is one of mnemonic tools. Research about mnemonic using in memorizing parts of lessons are also produced from time to time, such as David J. Burrel's work about remembering ceremonial law by drawing circle which contained sacred places, times, and ministers in Christianity. Burrel developed a method to help us memorize the ceremonial stuff (Burrel: 1888). This research is purposed to find a solution for everyone who has a problem in memorizing Qur'an, which is by using rhymes of Qur'an as mnemonic. I have not found any reference or literature about that issue. Moreover, this article is experimental field research.

\section{Music and Rhyme as A Tool to Memorize Qur'an}

In the earliest part of his book, Michael Sells portrayed the situation of a cafe in the afternoon in Cairo, which many people were gathering in front of a television to watch Egypt's professional Qur'an reciters were reciting Qur'an. The same view occurred in his lobby hotel where many people were watching and listening to the Qur'an recitation with huge interest. The beauty of Qur'anic language has been recognized within Muslims' and even non-Muslims' world. Besides, another beauty of Qur'an that also becomes the miracle of it as well as its beauty of language is the voice. The voice of Qur'an, if it is recited properly especially in Arabic style, can magically touch the listeners' heart and even bring them in tears, as what happened to Umar bin Khattab like many traditions told (Sells: 2001). In her phenomenological research, Anne K. Rasmussen noticed that Indonesian Qur'anic recitations sound Arab. They taught by the teacher to recite Qur'an in Arabic style since "this is the music of the Qur'an." Her research subjects $\mathrm{H}$. Moersjid Qari Indra and $\mathrm{Hj}$. Maria Ulfa were two professional reciters and also tilawah teacher in IIQ who currently were invited to be judges in MTQ (Musabaqah Tilawatil Qur'an/ competition in Qur'anic recitation). They shared their experiences and knowledges of Qur'anic recitation to Rasmussen, and she found that "Indonesian reciters embody the patterns of Arab music and share them among themselves and their students through a process" (Rasmussen: 2001). The most important thing to be noted here is that Qur'an is very musical in any styles to recite it if it is recited by proper application of ordinance along with it.

The purpose of reciting Qur'an is not always to look for the information which said as the guidance of Muslims' life, as one of Qur'anic functions that it is as the Guidance $(A l-H u d a)$. Yet, it is also for presenting the musical nuance that Qur'anic recitations created (Amstrong: 2004). Some people even play the record of it from some well-known professional reciters like As-Sudais, as a music bringing them asleep or called as the lullaby. Its musical brings tranquility and peace. Again, there are some elements constructing the music of Qur'an. 
The way to say a letter of Arabic (makharijul huruf) is not uniformed in the whole world, it is influenced by local dialect and style of reciting Qur'an (Robinson: 2001). Indonesians' dialect is also diverse since it has many languages of each region. Nonetheless, it is relatively easy to follow others' dialect. Besides, as I have underlined above from Sells' and Rasmussen's discovery, Indonesian style of reciting Qur'an sounds Arabic. In general, I can say that Indonesians' makharijul huruf are relatively same to Arabs. There are specific 17 makharijul huruf in tajwid which divided into general 5, they are: Al-Jauf (alif, waw, and ya), Al-H\}alq (h\}a, 'ain, kha, ghain), Al-Lisan (qaf, kaf, jim-shin-ya, d;ad, lam, nun, ra, t\}a-da-ta, d\}ad-dha-tha, s\}ad-za-sin), al-Shafatayn (fa, mim-ba) and al-Khayshum (mim and nun ghunnah (stressing)) (IKAT: 2017). Makharijul huruf also influenced by the nature of the letter which devided into two, without opposition (specific 8; s\}afir, qalqalah, layn, inh\}iraf, takrir, tafashi, is\}t\}ilah) and with opposition (specific 11; jahr and hams, shiddah and rakhawah, isti'la' and istifal, it 'baq and infitah\}, idhlaq and is\}mat).

Beside makharijul huruf, arts of recitation are also employed in constructing musical of Qur'an. There are three standards of reciting Qur'an, they are: hadr (the rapid is like normal talking speech), tartil (slow), and tadwir (medium), the rapid of recitation is not kind of problem as long as the reciters keep employing the ordinance of tajwid in it and the music of Qur'an will be preserved still (Robinson: 2001).

Another element constructing music of Qur'an is rhyme. There are at least three kinds of rhyme; they are: imperfect (slant rhyme), polysyllabic (mosaic rhyme), and internal (Hirjee: 2010). Imperfect rhyme is when two syllables do not exactly correspond, the voice is likely same, however it is still different. Example:

Wa l-'as\}ri

Inna l-insāna lafì khusrin

The verses quoted above is from Al-'As\}r:1-2. The nucleus (vowel) of verse 1 is a (fath $; a h)$ and the coda (consonant) is $s\}$ ad and ra. While verse 2, the nucleus is $\mathrm{u}$ (d)ammah) and the coda is sin. Both s\}ad and sin are expelled from the same spot; it is alLisan (tongue). However, $s\}$ ad and sin are different letters since the way to pronounce them are not same. Increasingly with the different nucleus before the coda, the rhymes are imperfect.

The second one is polysyllabic rhyme or mosaic rhyme, the same sounds occur in more than two syllables and it has unstressed syllable in it. Example:

A-lam nashrah laka s\}adrak

Wa wad\}a'nā 'anka wizrak

Al-ladhī 'anqada z\}ahrak

Wa rafa 'nā laka dhikrak

The example above, comes from al-Insyirah: 1-4. There are multiple syllables in the verses above and you can notice it in glimpse that the verse sound likely same even the words using are exactly different. The using of $f a t h\} a h$ ra and ended by kaf uniforms the rhymes. Moreover, all of coda before ra are sukun (becomes coda).

The third is internal rhyme, it is different from the two previous rhymes since it occurs inside the passages (not in the end of the line) and multiple times. Examples:

Huwa l-awwalu wa l-ākhiru

Wa $z$ \}-z\}āhiru wa l-bāt\}inu

Wa huwa bi-kulli shay'in 'alìm

The example comes from $\mathrm{Al}-\mathrm{H}\}$ adid:3 shows multiple rhymes inside a passage which are the using of $d\}$ ammah in four words. $\mathrm{U}$ ends each and connected by waw as alat al-'at\} $f$ (conjunction word), following each other contiguously. This kind also called 
chain rhyme, as part of internal rhyme, because it is shaped the chain connected one to other previous rhymes.

Both tajwid and rhymes are learnable. There are vast theories about them that the students can reach. The problem is the application of both in reciting and memorizing Qur'an. All of the students that I handled to finish their target that given one month only as the time limit to finish are asked to re-learn IQRA` from part 1 until 6, which normally are taught to Muslim's children when they start going to kindergarten on 4-8 years old. When they finish IQRA' they should have been able to read Qur'an fluently. In some cases, chaos is happened, that the children are still unable to recite Qur'an well. In my opinion, it must be there some steps skipped in the learning process. It could be the way to express a letter or specific ordinances of tajwid like mad, nun sukun ordinance, or mim sukun one. Another possibility that happened is that the students understand the tajwid cognitively, which means that they might have memorized all of makharijul huruf but they can not applicate them or memorized all of the ordinances in tajwid but they do not recognize them in recitation.

I have frequently asked my students when they recite Qur'an before delivering their memorization and found that they exactly known what ikhfa', idzhar, iqlab, mad ashli, mad ja iz, etc., even known what the meaning of each term and how is the ordinances prevailed for them. When they recite Qur'an and find them, they just do not recognize. For example, one of them recite:

Mut $\} \bar{a}$ 'in thamma ami $>n$, wa $m \bar{a} s\} a>$ hibukum bi majnu $>n$.

There is ikhfa' in it since 'ain kasratayn meets tha, the letter of $i k h f a$ ' and reciter must recite it obscurely and stress it for a while. In the second verse, there is ikhfa' syafawi since sukun mim meets ba, the only letter of it. it must be recited stressing (ghunnah). Unfortunately, she did not recite them as they must be. The ordinances are ignored, and it breaks the musical side of the verses. Surprisingly, when I asked her "what it is (the ordinances prevailed)" she shook his head, "have you ever learned about ikhfa" and ikhfa syafawi?" I continued, and she nodded her head. "How is it" I asked then she answered "ikhfa " means hazil (obscure) and when we read, we must stress it". "what is the letter of ikhfa "?" and she mentioned most than 5 letters that she remembered well and others like guessing and I helped her to complete. She understood the theory but failed in practices.

All I can do is helping them re-learn IQRA', the basic material in Qur'an recitation learning in Indonesia while underlining and highlighting the theories consecutively with its practices. Some of them have just reached part 2 now, and there is a little bit development in their recitation. I bet that the significant results will be earned if they have finished all of the parts, while the rhyme is also demanded to be recognized as well as tajwid. In my opinion, the difficulty of it is because not all of Muslim are Arabs, the owner of Qur'anic language. I do not exactly know whether all of them have the same awareness of Qur'anic rhymes or not, but I am sure that they are better than un-native speakers. However, it is still devised efforts. The easiest rhyme to recognize is perfect rhyme, and there are dozens of perfect rhymes in juz 'amma. The reciters must have recognized them since it is extremely clear. As what Chapter al-Takwir exhibits, it keeps with the same sounds from verse 1-14, using fath $\} a h$ as the nucleus and sukun ta as the coda. It is amazingly perfect.

What I do to the students to resuscitate them of rhymes in Qur'an is underlining their Qur'an by pen while they are delivering their memorization in front of me and I am holding their Qur'an scrutinizing their recitation. Every time I get them confused about the end of the verse I underline the passage while correcting them. When they have finished a chapter, I show them the underlines and ask them to scrutinize the underlines; 
then I explain the errors and the way they should remember the corrections. So far, I have not found yet the more effective and smart method to help the students recognizing the rhymes which support them to memorize Qur'an easily. However, I have to say that the underlining method has affected the memorization since they have known the lack and error in their memorization and could correct them by giving more attention to the passages or words I underlined.

In the table below, I will show the progress that the students made after guiding by tahsin qira 'ah and underlining method (in one month):

\begin{tabular}{|l|l|l|}
\hline No. & Name & Unfinished Obligation \\
\hline 1. & Arsyta & 5 chapters of juz 30 \\
\hline 2. & Cut Mardhati Azima & 9 chapters of juz 30 \\
\hline 3. & Dara Maghfirah Hanum & 39 verses of juz 1 and 25 verses of juz 30 \\
\hline 4. & Cut Adinda Maghfirah & 68 verses of juz 1 \\
\hline 5. & Fairuza Nadhifa & 70 verses of juz 1 \\
\hline 6. & Gusti Nabila Pratiwi & 6 chapters of juz 30 \\
\hline 7. & Izzah Raichan & 7 chapters of juz 30 \\
\hline 8. & Maghfirah & 17 verses of juz 1 \\
\hline 9. & Miftahul Jannah & 45 verses of juz 1 \\
\hline 10. & Muharrami Shalafina & 13 verses of juz 1 and 1 chapter of juz 30 \\
\hline 11. & Nuzulia Putri & 8 chapters of juz 30 \\
\hline 12. & Nursyahira Agustina & 14 chapters of juz 30 \\
\hline 13. & Rara Miftahul Jannah & 40 verses of juz 1 \\
\hline 14. & Thifal Bareen & 11 chapters of juz 30 \\
\hline 15. & Rifqatul Hurriyyah & 72 verses of juz 1 \\
\hline 16. & Ulfi Ladaya & 2 chapters of juz 30 \\
\hline 17. & Cut Rivka Ulfia Saputri & 7 chapter of juz 30 \\
\hline 18. & Nanda Mahfuzah & 26 verses of juz 1 \\
\hline
\end{tabular}

\begin{tabular}{|l|l|l|}
\hline No. & Name & Unfinished Obligation \\
\hline 1. & Arsyta & 2 chapters of juz 30 \\
\hline 2. & Cut Mardhati Azima & 3 chapters of juz 30 \\
\hline 3. & Dara Maghfirah Hanum & 10 verses of juz 1 \\
\hline 4. & Cut Adinda Maghfirah & Done \\
\hline 5. & Fairuza Nadhifa & Done \\
\hline 6. & Gusti Nabila Pratiwi & Done \\
\hline 7. & Izzah Raichan & 5 chapters of juz 30 \\
\hline 8. & Maghfirah & Done \\
\hline 9. & Miftahul Jannah & 20 verses of juz 1 \\
\hline 10. & Muharrami Shalafina & Done \\
\hline 11. & Nuzulia Putri & 2 chapters of juz 30 \\
\hline 12. & Nursyahira Agustina & 10 chapters of juz 30 \\
\hline 13. & Rara Miftahul Jannah & Done \\
\hline 14. & Thifal Bareen & 7 chapters of juz 30 \\
\hline 15. & Rifqatul Hurriyyah & 10 verses of juz 1 \\
\hline 16. & Ulfi Ladaya & Done \\
\hline 17. & Cut Rivka Ulfia Saputri & Done \\
\hline 18. & Nanda Mahfuzah & Done \\
\hline
\end{tabular}

table 2; after 
The examination is effective for some students and uneffective for others. The indicator is in the obligations they could finish in a month. The times given are same for all students to finish the target, whether they still have many obligations or not. It also influences by their diligence to deliver their memorization and learn Iqra', since I did not give the certain schedule for the students. I assume the students can reach their target if they were consistent in delivering their memorization. Unfortunately, some of them were not.

\section{Conclusion}

Based on my research, the subjects have been observed by the phenomenological approach. The phenomenon is some of them have a problem in memorizing Qur'an and I found the causes are the errors and lacks in practicing tajwid and unrecognizing rhymes in Qur'an. The steps I did to help them memorizing Qur'an easily were by re-learning the basic thing of recitation, beginning with makharijul huruf material, continuing with tajwid ordinances. Besides, I also did underlining method to recognize the rhyme within the verses so that they could relate one verse to the verses after it. Those simple steps however slowly but sure improve the subjects memorizing skill and the process of learning is still on going. I hope that I can discover a further more effective method to help every people with the same problem and this research is opened to everyone expanding.

\section{References}

Ahkam Al-Tajwid, Maktabah Syamilah Software. Vol.1, p.1.

Akbar, Abul Haris. (2010). Musikalitas Al-Qur'an (Kajian Unsur Keindahan Bunyi Internal dan Eksternal). Yogyakarta: Qur'anic Sciences and Exegesis Major, Faculty Theology and Islamic Thought, UIN Sunan Kalijaga.

Amstrong, Karen. (2004). Sejarah Tuhan Kisah Pencarian Tuhan Yang Dilakukan oleh orang-Orang Yahudi, kristen, dan Islam Selama 4.000 Tahun, translated by Zainul Am. Bandung: Mizan.

Bakken, Jeffrey P. and Cynthia G. Simpson. (2011). "Mnemonic Strategies: Success for the Young-Adult Learner" in The Journal of Human Resource and Adult Learning, Vol. 7, No. 2.

Bull, Victoria (ed.). (2011). Oxford Learner's Pocket Dictionary. New York: Oxford University Press.

Burrel, David J. (1888). "The Ceremonial Law. A Normal Lesson; With Mnemonic Helps" in The Old Testament Student, Vol. 7, No. 9.

Hirjee, Hussein. (2010). Rhyme, Rhythm, and Rhubarb Using Probalistic Methods to Analyze Hip Hop, Poetry, and Misheard Lyrics. Canada: Computer Science Major of University of Waterloo.

Ong, Walter J. (2005). Orality and Literacy: The Technologizing of The Word. Taylor \& Francis E-Library.

Student Academic Resource Center. 9 Types of Mnemonics for Better Memory. Florida: University of Central Florida.

Sells, Michael. (2001). Approaching The Qur'an. Oregon: White Cloud Press.

Rasmussen, Anne K. (2001). "The Qur'an in Indonesian Daily Life: The Public Project of Musical Oratory" in Ethnomusicology Winter 2001.

Robinson, Neil. (2001). Discovering the Qur'an A Contemporary Approach to A Veiled Text. London: SCM Press.

Tim Tahsin IKAT Aceh. (2017). Panduan Tahsin Tilawah al-Qur'an Metode Awsath. Banda Aceh: IKAT 